\title{
AROUSING INTEREST AND CURIOSITY IN INITIAL DYADIC INTERACTIONS: VERBAL AND NONVERBAL BEHAVIOURS IN A CONTEMPORARY MEDIA DATING CONTEXT
}

\section{Romaniuk O. S.}

\section{INTRODUCTION}

The art of arousing interest and curiosity is of crucial importance, especially in an attempt at making the first impression in face-to-face dyadic encounters. Both curiosity and interest transform boring encounters into rewarding ones as they are associated with greater positive emotions and greater closeness when socializing with a potential partner ${ }^{1}$. Over the last two decades, communication researchers have emphasized the influence of initial dyadic interactions in determining the likelihood of relationship development ${ }^{2}$. Thus, to reduce tension, attract attention, arouse interest and curiosity, as well as bolster initiation of romantic relationships, the potential partners may use a communicative hook in initial dyadic interactions. The communicative hook is defined as a strong statement, a personal experience, or a specific question that immediately provides the initiation of relationships ${ }^{3}$. Although the communicative hook strongly influences positive romantic outcomes in initial dyadic encounters, little is known about what should be said (i. e., verbal behaviour) and how it should be said (i. e., nonverbal behaviour) to arouse the interest and curiosity of a potential romantic partner in face-to-face dyadic interactions to initiate romantic relationships.

${ }^{1}$ Kashdan T.B., McKnight P.E., Fincham F.D., Rose P. When curiosity breeds intimacy: Taking advantage of intimacy opportunities and transforming boring conversations. Journal of Personality. 2011. Vol. 79. Iss. 6. P. 1369-1401. URL: https://doi.org/10.1111/j.1467-6494.2010.00697.x.

Paul E.L., Wenzel A., Harvey J. Hookups: A facilitator or barrier to relationship initiation and intimacy development? Handbook of relationship initiation / eds. : S. Sprecher, A. Wenzel, J. Harvey. New York : Psychology Press, 2008. P. 375-390. URL: https://doi.org/10.4324/9780429020513.

${ }^{2}$ Berscheid E., Regan P. The psychology of interpersonal relationships. Englewood Cliffs, NJ : Prentice Hall, 2005. 562 p.

Knapp M.L., Vangelisti A.L. Interpersonal communication and human relationships. Boston, MA : Allyn \& Bacon, 2010. 464 p.

${ }^{3}$ Browning S. A Fish Story. Denver : Outskirts Press, 2013. 70 p. 
Consequently, a partner's wish to talk further, go on a date, and even initiate romantic or sexual relationships, is likely to fall under the influence of the communicative hook. However crucial the usage of the communicative hook may be, little is known about the gender-related preferences regarding verbal and nonverbal behaviours implemented within this hook by the opposite-sex strangers in the mixed dyads. Yet, gender is found to affect the choice of verbal behaviours in face-to-face encounters ${ }^{4}$; as well as men and women are believed to have different repertoires of nonverbal behaviour ${ }^{5}$. Therefore, the focus of the present research is on the female preferences for verbal and nonverbal behaviours implemented within the communicative hook in initial dyadic interactions. The valuable insight into the verbal and nonverbal behaviours within the communicative hook is an important undertaking, one with implications for communication researchers, pick-up artists, seduction experts, dating coaches, and other experts in this field.

\section{Verbal and nonverbal behaviours}

Verbal behaviour was described as stylistic differences in expression from which we infer like or dislike 6 . Similarly, language expresses more than ideas, and a picture is not worth a thousand words as the addressee infer from speakers' language styles their attitude, moods, and affiliation ${ }^{7}$. Specifically, potential partners may communicate their interest, attraction, openness, willingness to continue relationships, and other feelings through a variety of verbal cues, e. g., compliments, humour, informal forms of address, self-disclosure, affectionate loving nicknames, etc. To emphasize the aforementioned feelings as well as initiate romantic relationships by arousing interest and curiosity, these verbal cues may be combined and/or transformed into the communicative hook. Thus, the correct choice of verbal

${ }^{4}$ Romaniuk A.S. Comparative analysis of the morphological features of the male and female corpora based on the American dating show "The Bachelor US' contestants" speech. Analele Universităţii din Craiova. Seria Stiinte Filologice, Lingvistica. 2016. Anul XXXVIII. № 1-2. P. 96-105.

5 LaFrance M., Vial A.C. Gender and nonverbal behavior. APA handbook of nonverbal communication / eds. : D. Matsumoto, H.C. Hwang, M.G. Frank. Washington, DC : American Psychological Association, 2016. P. 139-161. URL: https://doi.org/10.1037/14669-006.

${ }^{6}$ Mehrabian A., Wiener M. Decoding of inconsistent communications. Journal of Personality and Social Psychology. 1967. Vol. 6. Iss. 1. P. 109-114. URL: https://doi.org/10.1037/h0024532.

7 Bradac J.J., Bowers J.W., Courtright J.A. Three language variables in communication research: Intensity, immediacy, and diversity. Human Communication Research. 1979. Vol. 5. Iss. 3. P. 257-269. URL: https://doi.org/10.1111/j.14682958.1979.tb00639.x. 
cues is significant in face-to-face dyadic encounters as it facilitates the communicative goal achievement.

Positively, nonverbal behaviour, amplifying the verbal messages ${ }^{8}$, also plays a crucial role in communicative endeavours ${ }^{9}$. Ray Birdwhistell, the pioneer in nonverbal communication, pointed out that 30-35 per cent of the message meaning of interaction is conveyed by words and up to 65 per cent is communicated through nonverbal cues ${ }^{10}$. According to the studies of the nonverbal aspects of interactions, the results have suggested three basic components: the communication environment, which includes physical and spatial aspects; the individuals' physical characteristics; and the various behaviours manifested by the communicators. The third component was subdivided into body movement and position, gestures, posture, touching behaviours, facial expressions, and eye behaviour ${ }^{11}$.

Moreover, the nonverbal cues are particularly helpful to make inferences about both partners in initial romantic interactions ${ }^{12}$, since they constitute 93 per cent of inferred meanings ${ }^{13}$. Likewise, nonverbal communication was defined as complementary to speech as it is essentially less structured than verbal, non-linear, and spontaneous ${ }^{14}$. Given that the substantial part of the initial dyadic communication is nonverbal, the lack of the ability to understand and interpret the nonverbal signals is likely to lead to the communication failure of arousing interest and curiosity in face-to-face romantic encounters. Thus, not to misinterpret or ignore the partner's nonverbal messages, mastering the nonverbal communication skills is also essential. It is worth noting that the efforts to distinguish clearly between the

${ }^{8}$ Manusov V.L., Patterson M.L. The Sage handbook of nonverbal communication. Thousand Oaks, CA : Sage, 2006. 616 p.

${ }^{9}$ Burgoon J.K., Stern L.A., Dillman L. Interpersonal adaptation: Dyadic interaction patterns. New York : Cambridge University Press, 1995. 334 p. URL: https://doi.org/10.1017/CBO9780511720314.

${ }^{10}$ Birdwhistell R.L. Kinesics and content: Essays on the body motion communication. Philadelphia, PA : University of Pennsylvania Press, $1970.352 \mathrm{p}$. URL: https://doi.org/10.9783/9780812201284.

11 Knapp M.L., Hall J.A., Horgan T.G. Nonverbal communication in human interaction. Boston, MA : Wadsworth, 2014. 528 p.

${ }^{12}$ Hall J.A., Andrzejewski S.A., Yopchick J.E. Psychosocial correlates of interpersonal sensitivity: A meta-analysis. Journal of Nonverbal Behavior. 2009. Vol. 33. P. 149-180. URL: https://doi.org/10.1007/s10919-009-0070-5.

${ }^{13}$ Mehrabian A., Wiener M. Decoding of inconsistent communications. Journal of Personality and Social Psychology. 1967. Vol. 6. Iss. 1. P. 109-114. URL: https://doi.org/10.1037/h0024532.

14 Kouros C.D., Cummings E.M. Transactional Relations between Marital Functioning and Depressive Symptoms. American Journal of Orthopsychiatry. 2011. Vol. 81. P. 128-138. URL: https://doi.org/10.1111/j.1939-0025.2010.01080.x. 
verbal and nonverbal systems have been unsuccessful since they operate together as a part of the larger communication process ${ }^{15}$. Given that the verbal behaviour is accompanied by the nonverbal behaviour, both behaviours are assumed as interdependent, inseparable, and complementary. Therefore, both verbal and nonverbal behaviours came into the focus of our current research.

Moreover, the choice of verbal and nonverbal behaviours within the communicative hook is affected by two interdependent variables: the context (i. e., objective integrative features: place, setting, time, time spent together, etc.), and the communicators (i. e., subjective integrative features: gender, age, education, previous dating experience, cultural background) ${ }^{16}$. Thus, the current research investigates how the communicative goal to arouse the interest and curiosity in a contemporary dating context (i. e., objective integrative features) is achieved through the combination of verbal and nonverbal behaviours employed by the opposite-sex perfect strangers (i. e., subjective integrative features) in face-to-face romantic encounters.

The combination of the verbal and nonverbal behaviours in the communicative hook in initial dyadic interactions allowed us to address two issues. First, we address a gap in the initial romantic communication literature on the differential effects of the communicative hook ${ }^{17}$. Second, we contribute to a recent debate in the social behaviour literature: to maximize the efficiency of arousing the interest and curiosity by offering insights into the verbal and nonverbal behaviours of the communicative hook $^{18}$. The reviewed literature clearly indicates that the communicative hook is an essential facet of building overall interpersonal communication competence in initial dyadic interactions.

\section{Contemporary media dating context}

The increasing popularity of reality TV led to a paradigm shift in studies of changing social and cultural norms, gender stereotypes, and traditional gender roles in intimate relationships. The international dissemination of the

15 Knapp M.L., Hall J.A., Horgan T.G. Nonverbal communication in human interaction. Boston, MA : Wadsworth, 2014. 528 p.

${ }^{16}$ Romaniuk A.S. Basic universal units and components of romantic discourse based on the dating show patterns of dyadic interaction. Analele Universităţii din Craiova. Seria Stiinte Filologice, Lingvistica. 2017. Anul XXXIX. № 1-2. P. 370-380.

${ }^{17}$ Watson D., Klohnen E.C., Casillas A., Simms E.N., Haig J., Berry D.S. Match makers and deal breakers: Analyses of assortative mating in newlywed couples. Journal of Personality. 2004. Vol. 72. Iss. 5. P. 1029-1068. URL: http://dx.doi.org/10.1111/j.00223506.2004.00289.x.

18 Wood J.T. Interpersonal communication: Everyday encounters. Boston, MA : Cengage, 2013. 432 p. 
reality dating shows The Bachelor in more than twenty-six countries aroused the scientific interest in terms of cross-cultural interpersonal relationship standards and gender-related preferences within the media romantic domain. Consequently, these dating shows, providing a contemporary media dating context for understanding how initial romantic encounters may be formed, developed, or destroyed, also merit our attention.

Practically, the media dating behaviours are presented by the male "bachelors" and the female "bachelorettes" on the dating shows The Bachelor US (2002 - present). According to the format of these dating shows, the first round of the dating competition (i. e., the first episode in every season), the female contestants (approx. 25-30) try to impress a single bachelor during initial romantic encounters. The first impression rose is presented as a result of their success, i. e., whether female contestants managed to impress a potential date or not. Thus, according to the first impression outcome, all female contestants are grouped into two categories according to their partners' choice whether to go on a date or not (i. e., the second round). The first group is "the winners", i. e., those who managed to impress the potential partner and advanced to the second round. The second group is "the losers", i. e., those whose attempts to woo single bachelors failed, and, as a result, they were eliminated in the first round.

While watching reality shows, viewers absorb the ideas, morals, and views depicted by the contestants ${ }^{19}$. For instance, young viewers may seek romantic relationship advice in reality dating shows ${ }^{20}$. Moreover, reality dating shows are considered as significant cultural objects ${ }^{21}$. Similarly, the dating show format represents an opportunity to document changing cultural standards, providing the viewers with the rudiments of verbal and nonverbal behaviours enacted by perfect strangers in face-to-face romantic encounters $^{22}$. Thus, reality dating shows also merit exploration as a significant cultural object which could contribute a great deal to the study of reality TV.

${ }^{19}$ Bilandzic H. The Perception of Distance in the Cultivation Process: A Theoretical Consideration of the Relationship Between Television Content, Processing Experience, and Perceived Distance. Communication Theory. 2006. Vol. 16. Iss. 3. P. 333-355. URL: https://doi.org/10.1111/j.1468-2885.2006.00273.x.

${ }^{20}$ Ferris A.L., Smith S.W., Greenberg B.S., Smith S.L. The Content of Reality Dating Shows and Viewer Perceptions of Dating. Journal of Communication. 2007. Vol. 57. Iss. 3. P. 490-510. URL: https://doi.org/10.1111/j.1460-2466.2007.00354.x.

${ }^{21}$ Montemurro B. Toward a Sociology of Reality Television. Sociology Compass. 2007. Vol. 2. Iss. 1. P. 84-106. URL: https://doi.org/10.1111/j.1751-9020.2007.00064.x.

22 Romaniuk O.S. The First Impression Matters: The Art of Male Romantic Communication in American Media Dating Culture. Discourse and Interaction. 2020. Vol. 13. Iss. 1. P. 67-91. URL: https://doi.org/10.5817/DI2020-1-67. 


\section{Methodology}

For this study, the communicative hooks enacted by the female "bachelorettes" $(N=189)$ on the dating show The Bachelor US $(2012-2019)^{23}$ during initial romantic encounters were analysed. It is worth noting that data came from a larger project on initial romantic relationships, and should provide sufficient statistical power (>.80), which means that the test results are likely to be valid and the sample size is large enough. The dating show is recommended to discuss as discourse since it shows a great degree of complexity. Therefore, to address the issue regarding verbal and nonverbal behaviours within the communicative hook, the current research applied interactional sociolinguistics $^{24}$, as one of the approaches to discourse analysis. Thus, both qualitative interactive sociolinguistic and quantitative analyses were used.

At one extreme, the qualitative interactive sociolinguistic analysis involves video recordings of the initial dyadic interactions enacted by the female "bachelorettes" on the dating show The Bachelor US. The one gives information regarding the functioning of the communicative hook in face-toface romantic encounters and a variety of the verbal and nonverbal behaviours employed by the potential partners. At the other extreme, the quantitative analysis presents the frequency and, accordingly, preferences for the verbal and nonverbal behaviours enacted by women within the communicative hook in face-to-face romantic encounters.

Specifically, there are three key components of the qualitative interactive sociolinguistic analysis: the objective integrative features, the subjective integrative features, and the strategic ways. Firstly, the objective integrative features include romantic place and setting, evening time, time spent together, which varied from 5 seconds to 58 seconds $\left(M_{\text {interaction }}=29,5\right.$ seconds, $S D=$ 10,3). The communication environment of the initial romantic encounters encompasses: 1) perceptual bases for environments (i. e., informal, warm, private, unfamiliar, free, and close); 2) fixed environmental features (i. e., romantic physical environment: romantic settings, evening time, dim and soft lighting, natural sounds); 3) varying environmental features (i. e., spatial environment: intimate - casual - personal).

However, in the case of the objective integrative features, a contemporary media dating context has some limitations in comparison with actual dating context. Firstly, this highly-competitive dating environment is considered to be atypical as most people do not go on dates and compete against 30 other people. Thus, we could not generalize our conclusions regarding "reality" of

${ }^{23}$ The Bachelor US (2012-2019). Seasons 16-23 (E1601; E1701; E1801; E1901; E2001; E2101; E2201; E2301). URL: https://abc.com/shows/the-bachelor.

${ }^{24}$ Gumperz J. Discourse Strategies. Studies in Interactional Sociolinguistics. Cambridge : Cambridge University Press, 1982. 238 p. 
initial romantic interactions depicted by female contestants due to not naturally-occurring dating environment. Secondly, there is editing that is used to create a story. However, this limitation has been overcome since we choose face-to-face romantic encounters which were only presented in the whole. This allowed us to analyse the whole data chunk not affected by the editing process. Yet, this choice led to reducing the number of female contestants from 225 (i. e., original number) to 189 (i. e., actual number). Finally, line-by-line coding was performed to develop specific themes within every data chunk of the communicative hook implementation ${ }^{25}$ (table 1).

Table 1

\section{Line-by-line coding of dyadic interaction} (verbal \& nonverbal behaviours)

\begin{tabular}{|l|l|}
\hline \multicolumn{1}{|c|}{ Verbal behaviour } & \multicolumn{1}{|c|}{ Nonverbal behaviour } \\
\hline$\ldots$ & $\begin{array}{l}\text { Happiness, turning around to show } \\
\text { her hat }\end{array}$ \\
\hline M: Oh, my! Wow! That is the hat. & - \\
\hline $\begin{array}{l}\text { F: It's a clue to where I am from. } \\
\text { (Place of Residence) }\end{array}$ & $\begin{array}{l}\text { Happiness, mutual gaze, trunk } \\
\text { leaning forward, pointing at oneself } \\
\text { (breast touching), }\end{array}$ \\
\hline M: No idea. & - \\
\hline F: No idea? & $\begin{array}{l}\text { Surprise, mutual gaze, trunk leaning } \\
\text { forward, eyebrow flash }\end{array}$ \\
\hline M: Kentucky maybe. & - \\
\hline $\begin{array}{l}\text { F: That would be it. Do you know } \\
\text { what Kentucky is known for? ... } \\
\text { Two things. }\end{array}$ & $\begin{array}{l}\text { Happiness, mutual gaze, trunk } \\
\text { leaning forward, using fingers to } \\
\text { indicate numeric amounts }\end{array}$ \\
\hline M: Bourbon? & - \\
\hline $\begin{array}{l}\text { F: Oh, no! That's not the answer. } \\
\text { Keep going. }\end{array}$ & $\begin{array}{l}\text { Surprise, mutual gaze, trunk leaning } \\
\text { forward, eyebrow flash, head tilt }\end{array}$ \\
\hline M: Their women? & - \\
\hline $\begin{array}{l}\text { F: Their women. Oh, my gosh! } \\
\text { Kentucky is known for two things } \\
\text { and that is beautiful women and fast } \\
\text { horses. (Self-Praise) }\end{array}$ & $\begin{array}{l}\text { Surprise, mutual gaze, trunk leaning } \\
\text { forward, eyebrow flash, nodding, } \\
\text { happiness, wink, preening (hair } \\
\text { grooming) }\end{array}$ \\
\hline M: Aha. Well, all right, now I get it. & - \\
\hline
\end{tabular}

${ }^{25}$ Charmaz K. Constructing grounded theory: A practical guide through qualitative analysis. London : Sage, 2006. 416 p. 
As a result of the line-by-line coding analysis, verbal cues $(N=372)$ and nonverbal cues $(N=1138)$ were revealed. They were analysed using SPSS Statistics 23.

The subjective integrative features are as follows: the female "bachelorettes" are the United States citizens or resident aliens living in the United States; they are at least twenty-one years old, and not currently involved in a committed intimate relationship. Specifically, the female contestants' age ranged from 21 to $35\left(M_{\text {age }}=26,4\right.$ years, $\left.S D=2,7\right)$; their occupations were basically in the fields of Business, Service, Medicine, Education, and Fashion. The strategic ways of the communicative hook implementation are assumed as what should be said (verbal behaviour) and how it should be said (nonverbal behaviour) to arouse interest and curiosity of a potential romantic partner in initial dyadic interactions.

\section{Results}

To arouse interest and curiosity, the female "bachelorettes" implemented the communicative hooks, which were employed by the following formula: coded message/information + addressee's wish to receive an answer. The verbal intensification of the communicative hook occurred by holding the key facts, grabbing a partner's undivided attention at the beginning of the initial dyadic interactions.

The verbal behaviours of the communicative hooks were implemented within nine specific themes (i. e., verbal cues) aimed at revealing personal information on (1) Profession, (2) Place of Residence, and (3) Family; expressing a positive attitude towards one's approval or admiration regarding physical, intellectual, moral, social, and other personality traits within (4) Self-Praise and (5) Self-Presentation; outlining the probability of the further romantic relationships within (6) Continuation of Relationship; getting conversations started through (7) Identification, and (8) Emotional State; and paying (9) Compliments. Verbal behaviour, providing the realisation of the communicative hook in initial dyadic interactions, was characterised by different strategic ways of arousing interest and curiosity. The following examples of the verbal interpretation of the communicative hook were given to illustrate various strategic ways of its usage within the aforementioned verbal cues.

The most popular way of intensifying and furthering the initial dyadic interaction was to ask awkward, embarrassing, provocative, tricky, or even silly questions, e. g., "Do you love bacon?", "Do you want a little taste?". They usually confused and puzzled addressees giving the interaction their full attention, for example:

F: ...My name is Amber. And my last name is Bacon. My friends call me The Baconator. 
M: The Baconator?

F: Yeah, I am the Baconator. Do you love bacon?

M: Yeah?!

F: Come on, do you want a little taste?

M: Of Bacon, yeah?! Sure?!

F: So, kiss me! A little, uh?

M: I'm gonna taste some bacon?

F: How was it?

M: It makes everything better. Delicious! [The Bachelor US, 2012, Season 16, Episode 1].

A male's confusion was usually expressed by simple, one-word statements, and echo questions, e. g., "I'm gonna taste some bacon?". They demonstrated the communicative tension and intention to force the speaker to make the next move, which would clarify the key information.

Also, the communicative hook may be described by using an incomplete thought or idea. It enabled the addressee to come up with an end on their own, providing both a challenge and sexual interest in continuing the relationship, e. g., "So, make sure you'll find me later cause I'm gonna make you sweat a little bit, ok?". The daring verbal behaviour is expressed by the imperative form of a verb "make sure" accompanied by "you'll find me". This gives the bachelor the dominant role in initiating romantic relationships.

The communicative hook was found to be expressed within the single specific theme (i. e., one verbal cue):

- Communicative hook + Self-Praise: "I'm Miss North Carolina, but I'm here for an even better title, Miss Underwear Looking Good" [The Bachelor US, 2019, Season 23, Episode 1]. The bachelorette tries to arouse sexual interest and desire to take off her dress because she thinks that she looks better just wearing underwear. The communicative hook is expressed by the action (i. e., the bachelorette changes Miss North Carolina Beauty Pageant Sash with the text "Miss North Carolina 2018" into "Miss Underwear Looking Good"), and by verbal interpretation;

- Communicative hook + Self-Presentation: “...part of my heart is in Vienna, but another part is with you" [The Bachelor US, 2019, Season 23, Episode 1]. The bachelorette speaks Spanish describing her favourite place where she likes to travel. The bachelor expresses his interests in what she is saying and asks her to translate herself. The communicative hook is implemented by a foreign language (Spanish) and by verbal interpretation (translation) of a rather provocative statement "another part [of my heart] is with you", which is not typical for first encounters;

- Communicative hook + Emotional State: "I'm so nervous right now, I have so many butterflies here... so I hope no more butterflies ... though, 
you know, I feel like I still have a little bit of butterflies, but it's ok" [The Bachelor US, 2019, Season 23, Episode 1]. The communicative hook is implemented by verbal interpretation along with the action, i. e., the bachelorette shows a box full of butterflies to the bachelor, which represents her nervousness and excitement, and refers to a well-known saying "to have butterflies in one's stomach";

- Communicative hook + Family: "This is my ten-year-old daughter Lucy, and I'd like to give you a piece of my heart, so I'm gonna give you her. Take care of her" [The Bachelor US, 2019, Season 23, Episode 1]. The bachelorette brings her dog to the show asking the bachelor to take care of her "daughter", which arouses his interest, and, is perceived as a communicative hook;

- Communicative hook + Continuation of Relationship: "Well, I'm here looking for my Prince Charming. So, I really can't wait to get to know you better, come and find me before the clock strikes midnight" [The Bachelor US, 2019, Season 23, Episode 1]. The bachelorette comes to the show in a large carriage pulled by horses. Comparing herself with Cinderella, she leaves her shoe and asks the bachelor to find her later. The communicative hook is expressed by the bachelorette's appearance in the image of Cinderella from a fairy tale, and by verbal interpretation.

The verbal cues employed within communicative hooks could also be combined:

- Communicative hook + Self-Presentation + Continuation of Relationship: "So, I haven't dated a virgin since I was 12 but I'm excited to give it another shot" [The Bachelor US, 2019, Season 23, Episode 1]. The Bachelor is a virgin, and the bachelorette blows up a red balloon to show that she is ready to become his first woman. The communicative hook is implemented by a red balloon (as a symbol of innocence and virginity), the action (hinting at an ulterior motive), and the verbal interpretation, which clarifies her point;

- Communicative hook + Place of Residence + Self-Praise: "Have you ever tasted sweet Georgia peach, cause I have one for you, do you wanna try? I'm from Atlanta, Georgia that makes me sweet as Georgia peach" [The Bachelor US, 2019, Season 23, Episode 1]. The communicative hook is realised by a tricky question, which puzzles a bachelor, and by a verbal explanation (i. e., the bachelorette gives him a peach comparing its sweetness with her).

The communicative hooks could be also combined with three thematically different verbal cues, e. g., revealing personal information on a future Profession, Self-Praise, and paying a Compliment. The communicative hook is expressed by verbal interpretation, as the 
bachelorette accuses her potential partner of being sexy by the provocative statement "you are guilty". The bachelor's confusion was expressed by two consecutive echo questions, e. g., "Guilty? Guilty of what?", which would help him clarify the bachelorette's claim:

F: I am ... I am one of the best law students and you are guilty...

M: Guilty? Guilty of what?

F: Of .... being sexy [The Bachelor US, 2012, Season 16, Episode 1].

Also, one of the strategic ways of the verbal behaviour, using to attract the potential partner's attention and interest, was numbers, for example:

F: I am an accountant, so I'm gonna give you some numbers. Ready?

M: Yeah.

F: 1,190 is the number of miles I traveled to be here tonight.

M: Okay.

F: Zero is the number of times I have been arrested.

M: Okay

$F: 54$ is the number of dresses I tried on before picking this one.

M: Fifty-four, very nice.

F: You like?

M: Very much so.

$F$ : One is the number of times I have been in love.

M: Okay.

F: And hopefully after getting to know you a little better I can make it two [The Bachelor US, 2012, Season 16, Episode 1].

The female contestant uses the numbers within the verbal cue SelfPresentation, revealing personal information on her Profession. Moreover, the provocative question helps ascertain whether the bachelor likes her dress, and the verbal interpretation of Continuation of Relationship outlines her wish to get to know him better.

Despite the usage of these verbal cues $(N=372)$ in the communicative hook, their frequencies were different. In a survey analysis, the Cross Tabulation provided the understanding of the interrelation between nine verbal cues and the communicative hook. To analyse the female preferences for the aforementioned verbal cues, the (multivariate) frequency distribution of these variables were applied to reveal their presence or absence within every data chunk (figure 1). 


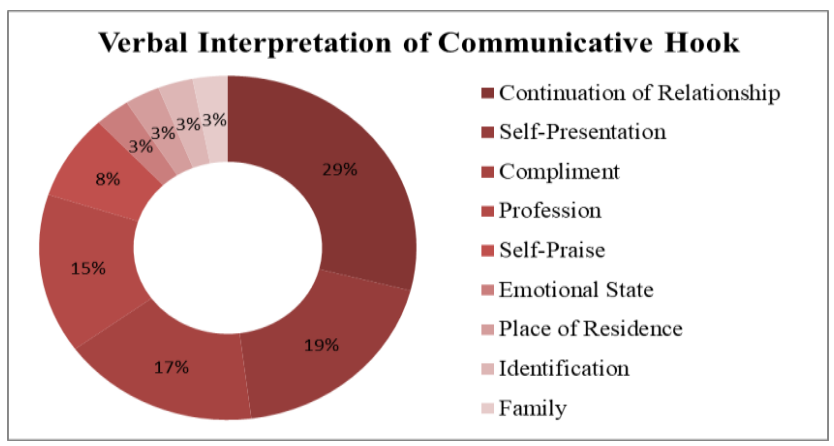

Fig. 1

The findings presented in Figure 1 showed that the most relevant verbal cues implemented within the communicative hook were Continuation of Relationship (29\%), Self-Presentation (19\%), Compliment (17\%), Profession (15\%), and Self-Praise (8\%).

The nonverbal behaviour, providing the realisation of the communicative hook in initial dyadic interactions, was categorized according to: 1) speechrelated gestures $(25,2 \%) ; 2)$ touching behaviour $(24,9 \%) ; 3)$ eye behaviour $(21,4 \%) ; 4)$ posture $(15,6 \%) ; 5)$ facial expression (13\%) (table 2).

As evident from the figures in table 2, these categories were employed by thirty-three subcategories of nonverbal cues $(N=1138)$ : twelve subcategories in speech-related gestures $(N=287)$; five subcategories in self-focused touching behaviour $(N=113)$ and five subcategories in otherfocused touching behaviour $(N=170)$; six subcategories in eye behaviour $(N=243)$; three subcategories in posture $(N=177)$; two subcategories in facial expression $(N=148)$.

The most expressive categories of nonverbal behaviour were speechrelated gestures, touching behaviour, and eye behaviour. Specifically, the most relevant nonverbal cues implemented within the communicative hook were as follows: head tilt, nodding, delivery gestures, upright posture, trunk leaning forward, holding hands in front of the body, hand-in-hand, hug, kiss, happiness, surprise, mutual gaze (forehead bow), gaze down, eyebrow flash.

Nonverbal cues also enabled a potential partner to draw inferences about true intentions. Practically, nonverbal cues, i. e., head tilt, nodding, hair tossing, turning around to show off, trunk leaning forward, hair grooming, clothes straightening, lower lip biting, happiness, surprise, mutual gaze (forehead bow), wink, and eyebrow flash, were immensely influential in demonstrating a bachelorette's wish to arouse interest and curiosity. 
Table 2

Communicative hook implementation by nonverbal behaviour

\begin{tabular}{|c|c|c|c|}
\hline Subcategory & Frequency, \% & Nonverbal cues & Frequency, \% \\
\hline \multicolumn{4}{|c|}{ Speech-related gestures $(25,2 \%)$} \\
\hline \multirow{3}{*}{ Head } & \multirow{3}{*}{12,9} & \begin{tabular}{|c|} 
Head tilt \\
\end{tabular} & 44,8 \\
\hline & & Nodding & 70,7 \\
\hline & & Hair tossing & 11,2 \\
\hline \multirow{2}{*}{ Shoulders } & \multirow{2}{*}{1,9} & Shoulder shrug & 6,9 \\
\hline & & Shoulder twisting & 12,1 \\
\hline \multirow{5}{*}{ Hands } & \multirow{5}{*}{8,8} & Pointing at a partner & 14,7 \\
\hline & & $\begin{array}{l}\text { Pointing at oneself (breast } \\
\text { touching) }\end{array}$ & 22,4 \\
\hline & & Delivery gestures & 32,8 \\
\hline & & High-five & 6,0 \\
\hline & & Sh-gesture & 10,3 \\
\hline \multirow{2}{*}{ Body } & \multirow{2}{*}{1,6} & Turning around to show off & 9,8 \\
\hline & & \begin{tabular}{|c|} 
Body tilt \\
\end{tabular} & 10,3 \\
\hline \multicolumn{4}{|c|}{ Touching behaviour $(\mathbf{2 4 , 9 \% )}$} \\
\hline \multirow{5}{*}{ Self-focused } & \multirow{5}{*}{9,9} & $\begin{array}{l}\text { Self-intimacies (holding } \\
\text { hands in front of body) }\end{array}$ & 50,0 \\
\hline & & $\begin{array}{c}\text { Self-intimacies (face } \\
\text { covering) }\end{array}$ & 24,1 \\
\hline & & $\begin{array}{l}\text { Self-intimacies (lower lip } \\
\text { biting) }\end{array}$ & 4,3 \\
\hline & & $\begin{array}{l}\text { Preening (clothes } \\
\text { straightening) }\end{array}$ & 12,9 \\
\hline & & Preening (hair grooming) & 6,0 \\
\hline \multirow{5}{*}{$\begin{array}{l}\text { Other- } \\
\text { focused }\end{array}$} & \multirow{5}{*}{14,9} & Hand-in-hand & 71,6 \\
\hline & & Hug & 31,9 \\
\hline & & Kiss & 29,3 \\
\hline & & Arm-link & 6,0 \\
\hline & & \begin{tabular}{|c|} 
Caress \\
\end{tabular} & 7,8 \\
\hline \multirow{5}{*}{ Gaze } & & behaviour $(21,4 \%)$ & \\
\hline & \multirow{4}{*}{16,9} & \begin{tabular}{|l} 
Mutual Gaze (forehead bow) \\
\end{tabular} & 100 \\
\hline & & Gaze down & 31,0 \\
\hline & & Gaze side(s) & 24,1 \\
\hline & & Gaze up & 10,3 \\
\hline Eyes & 1,5 & Wink & 14,7 \\
\hline Eyebrows & 3,0 & Eyebrow flash & 29,3 \\
\hline \multirow{4}{*}{ Trunk lean } & & Posture $(15,6 \%)$ & \\
\hline & \multirow{3}{*}{15,6} & Forward & 49,1 \\
\hline & & Backward & 3,4 \\
\hline & & \begin{tabular}{|c|} 
Upright \\
\end{tabular} & 100 \\
\hline \multirow{3}{*}{ Face } & & al expressions $(\mathbf{1 3 \%})$ & \\
\hline & \multirow{2}{*}{13,0} & Happiness & 100 \\
\hline & & Surprise & 27,6 \\
\hline
\end{tabular}


The communicative hook was also characterized by the following discourse features: 1) attitude towards the content (positive $-87,4 \%$ and neutral $-12,6 \%$ ); 2) means of realisation (internal - 82,3\%, combined $13,9 \%$, and external $-3,8 \%$ ); 3 ) means of expression (explicit $-64,7 \%$ and implicit $-35,3 \%)$. Accordingly, negative attitudes towards the content were not revealed in the verbal interpretation of the communicative hook.

\section{CONCLUSIONS}

Based on the above findings, the communicative hook within the female romantic communication in a contemporary media dating context was implemented through verbal and nonverbal behaviours, providing the successful communicative goal achievement, e. g., making the first impression, initiating romantic relationships, getting an invitation to a date, etc. Positively, both verbal and nonverbal behaviours are crucial to the success of arousing the interest and curiosity in initial dyadic interactions. Verbal behaviour of the communicative hook was expressed by the following verbal cues: Continuation of Relationship (29\%), SelfPresentation (19\%), Compliment (17\%), Profession (15\%), Self-Praise (8\%), Emotional State (3\%), Place of Residence (3\%), Identification (3\%), and Family (3\%).

Nonverbal behaviour, employed by the bachelorettes, was characterised by the following categories, listed in order from the most to the least expressive: 1) speech-related gestures $(25,2 \%)$; 2) touching behaviour $(24,9 \%) ; 3)$ eye behaviour $(21,4 \%) ; 4)$ posture $(15,6 \%) ; 5)$ facial expression $(13 \%)$. The communicative goal to arouse interest and curiosity was communicated through the following nonverbal cues:

1) speech-related gestures: a) head (nodding, head tilt); b) hands (delivery gestures);

2) posture - upright posture and trunk leaning forward;

3) touching behaviour: a) self-focused (self-intimacies, i. e. holding hands in front of the body); b) other-focused (hand-in-hand, hug, kiss);

4) facial expression: a) happiness; b) surprise;

5) eye behaviour: a) gaze (mutual gaze (forehead bow), gaze down); b) eyebrows (eyebrow flash).

Thus, these verbal and nonverbal communication skills facilitate competent communication in initial romantic encounters and help infer the potential partner's true intentions. Apart from practical implications, these findings could have general implications for theorizing on changing social and cultural standards, gender stereotypes, and traditional gender roles in intimate relationships. This contributes to the study of interactional sociolinguistics, i. e. verbal and nonverbal behaviours within romantic communication in a contemporary media dating context. The findings reported in this study may also point to some implications while teaching Interpersonal Communication Competence courses. 
Given that the effectiveness of a communicative hook comprises strategic ways of arousing the interest and curiosity of a potential romantic partner in face-to-face romantic encounters, both verbal and nonverbal behaviours came into the focus of our research. Practically, the insight into the aforementioned strategic ways helps one better appreciate the role of effective romantic communication in a contemporary media dating context. However, the current research has its limitations and further directions. The initial romantic encounters enacted by the potential partners of the dating show The Bachelor US are highly scripted, i. e., not spontaneous or in-themoment communications. Therefore, while theoretically plausible, the communicative hook has yet to be tested on actual dating behaviours. However, the current study can be considered as important complementation to the overall research project of making the first impression in face-to-face romantic encounters.

\section{SUMMARY}

A communicative hook contributes to positive romantic outcomes in initial dyadic interactions in a contemporary media dating context. The focus of the current research was on how the communicative goal "to arouse interest and curiosity" is achieved through the combination of verbal and nonverbal behaviours employed by the opposite-sex perfect strangers. The communicative cook was defined as coded message/information + addressee's wish to receive an answer that immediately arouses interest and curiosity of a potential partner. For this study, the communicative hooks enacted by the female contestants $(N=189)$ on the dating show The Bachelor US (2012-2018) during initial romantic interactions with the single bachelors were analysed. Verbal behaviour of the communicative hook was expressed by the following verbal cues: Continuation of Relationship, SelfPresentation, Compliment, Profession, Self-Praise, Emotional State, Place of Residence, Identification, and Family. The most relevant nonverbal cues implemented within the communicative hook were as follows: head tilt, nodding, delivery gestures, upright posture, trunk leaning forward, holding hands in front of the body, hand-in-hand, hug, kiss, happiness, surprise, mutual gaze (forehead bow), gaze down, eyebrow flash. They enabled a potential partner to draw inferences about bachelorettes' true intentions. Mastering verbal communication skills and not misinterpreting or ignoring partners' nonverbal messages could maximize the efficiency of the communicative hook. These findings could have general implications for theorizing on changing social and cultural standards, gender stereotypes, and traditional gender roles in intimate relationships. They could also contribute a great deal to the study of reality TV.

\section{REFERENCES}

1. Berscheid E., Regan P. The psychology of interpersonal relationships. Englewood Cliffs, NJ : Prentice Hall, 2005. 562 p. 
2. Bilandzic H. The Perception of Distance in the Cultivation Process: A Theoretical Consideration of the Relationship Between Television Content, Processing Experience, and Perceived Distance. Communication Theory. 2006. Vol. 16. Iss. 3. P. 333-355. URL: https://doi.org/10.1111/j.1468-2885.2006.00273.x.

3. Birdwhistell R.L. Kinesics and content: Essays on the body motion communication. Philadelphia, PA : University of Pennsylvania Press, 1970. 352 p. URL: https://doi.org/10.9783/9780812201284.

4. Bradac J.J., Bowers J.W., Courtright J.A. Three language variables in communication research: Intensity, immediacy, and diversity. Human Communication Research. 1979. Vol. 5. Iss. 3. P. 257-269. URL: https://doi.org/10.1111/j.1468-2958.1979.tb00639.x.

5. Browning S. A Fish Story. Denver : Outskirts Press, 2013. 70 p.

6. Burgoon J.K., Stern L.A., Dillman L. Interpersonal adaptation: Dyadic interaction patterns. New York : Cambridge University Press, 1995. 334 p. URL: https://doi.org/10.1017/CBO9780511720314.

7. Charmaz K. Constructing grounded theory: A practical guide through qualitative analysis. London : Sage, 2006. 416 p.

8. Ferris A.L., Smith S.W., Greenberg B.S., Smith S.L. The Content of Reality Dating Shows and Viewer Perceptions of Dating. Journal of Communication. 2007. Vol. 57. Iss. 3. P. 490-510. URL: https://doi.org/10.1111/j.1460-2466.2007.00354.x.

9. Gumperz J. Discourse Strategies. Studies in Interactional Sociolinguistics. Cambridge : Cambridge University Press, 1982. 238 p.

10. Hall J.A., Andrzejewski S.A., Yopchick J.E. Psychosocial correlates of interpersonal sensitivity: A meta-analysis. Journal of Nonverbal Behavior. 2009. Vol. 33. P. 149-180. URL: https://doi.org/10.1007/s10919009-0070-5.

11. Kashdan T.B., McKnight P.E., Fincham F.D., Rose P. When curiosity breeds intimacy: Taking advantage of intimacy opportunities and transforming boring conversations. Journal of Personality. 2011. Vol. 79. Iss. 6. P. 1369-1401. URL: https://doi.org/10.1111/j.14676494.2010.00697.x.

12. Knapp M.L., Vangelisti A.L. Interpersonal communication and human relationships. Boston, MA : Allyn \& Bacon, 2010. 464 p.

13. Knapp M.L., Hall J.A., Horgan T.G. Nonverbal communication in human interaction. Boston, MA : Wadsworth, 2014. 528 p.

14. Kouros C.D., Cummings E.M. Transactional Relations between Marital Functioning and Depressive Symptoms. American Journal of Orthopsychiatry. 2011. Vol. 81. P. 128-138. URL: https://doi.org/10.1111/j.1939-0025.2010.01080.x.

15. LaFrance M., Vial A.C. Gender and nonverbal behavior. APA handbook of nonverbal communication / eds. : D. Matsumoto, H.C. Hwang, 
M.G. Frank. Washington, DC : American Psychological Association, 2016. P. 139-161. URL: https://doi.org/10.1037/14669-006.

16. Manusov V.L., Patterson M.L. The Sage handbook of nonverbal communication. Thousand Oaks, CA : Sage, 2006. 616 p.

17. Mehrabian A., Wiener M. Decoding of inconsistent communications. Journal of Personality and Social Psychology. 1967. Vol. 6. Iss. 1. P. 109114. URL: https://doi.org/10.1037/h0024532.

18. Montemurro B. Toward a Sociology of Reality Television. Sociology Compass. 2007. Vol. 2. Iss. 1. P. 84-106. URL: https://doi.org/10.1111/j.1751-9020.2007.00064.x.

19. Paul E.L., Wenzel A., Harvey J. Hookups: A facilitator or barrier to relationship initiation and intimacy development? Handbook of relationship initiation / eds. : S. Sprecher, A. Wenzel, J. Harvey. New York : Psychology Press, 2008. P. 375-390. URL: https://doi.org/10.4324/9780429020513.

20. Romaniuk A.S. Basic universal units and components of romantic discourse based on the dating show patterns of dyadic interaction. Analele Universității din Craiova. Seria Stiinte Filologice, Lingvistica. 2017. Anul XXXIX. № 1-2. P. 370-380.

21. Romaniuk A.S. Comparative analysis of the morphological features of the male and female corpora based on the American dating show "The Bachelor US' contestants" speech. Analele Universității din Craiova. Seria Stiinte Filologice, Lingvistica. 2016. Anul XXXVIII. № 1-2. P. 96-105.

22. Romaniuk O.S. The First Impression Matters: The Art of Male Romantic Communication in American Media Dating Culture. Discourse and Interaction. 2020. Vol. 13. Iss. 1. P. 67-91. URL: https://doi.org/10.5817/DI2020-1-67.

23. The Bachelor US (2012-2019). Seasons 16-23 (E1601; E1701; E1801; E1901; E2001; E2101; E2201; E2301). URL: https://abc.com/shows/the-bachelor.

24. Watson D., Klohnen E.C., Casillas A., Simms E.N., Haig J., Berry D.S. Match makers and deal breakers: Analyses of assortative mating in newlywed couples. Journal of Personality. 2004. Vol. 72. Iss. 5. P. 10291068. URL: http://dx.doi.org/10.1111/j.0022-3506.2004.00289.x.

25. Wood J.T. Interpersonal communication: Everyday encounters. Boston, MA : Cengage, 2013. 432 p.

\section{Information about the author: Romaniuk O.S., \\ $\mathrm{PhD}$, Associate Professor,} Associate Professor at the English Language Department National University "Odesa Maritime Academy" 8, Didrikhson str., Odesa, 65029, Ukraine 